\title{
X-linked cleft palate and ankyloglossia
}

INSERM

\section{Source}

INSERM. (1999). Orphanet: an online rare disease and orphan drug data base. $\underline{X \text {-linked }}$ cleft palate and ankyloglossia. ORPHA:324601

X-linked cleft palate and ankylog lossia is a rare, genetic developmental defect during embryogenesis syndrome characterized by the association of complete, partial or submucous cleft palate and ankylog lossia. Patients may also present abnormal uvula (e.g. absent, bifid, shortened or laterally deviated), short lingual frenulum and dental anomalies (e.g. buccal crossbite, absent and/or misshapen teeth). Digital abnormalities, such as mild clinodactyly and/or syndactyly, have also been reported. 